\title{
Pengaruh Kombinasi Teh Kompos Berbahan Dasar Ekskreta Ayam dan Biochar Berbahan Dasar Sufmuti (Chromolaena odorata L.) terhadap Pertumbuhan dan Produksi Rumput Odot (Pennisetum purpureum cv. Mott)
}

\author{
Yustina Suri ${ }^{\mathrm{a}}$ \\ ${ }^{a}$ Fakultas Pertanian, Universitas Timor, Kefamenanu, TTU - NTT, 85613, Indonesia, email: yustinasuri1 @ gmail.com \\ ${ }^{a}$ Faculty of Agriculture, Timor University, Kefamenanu, TTU - NTT, 85623, Indonesia, email: yustinasuri1@ gmail.com
}

\section{Article Info}

\section{Article history:}

Received 04 April 2021

Received in revised form 11 April 202 Accepted 20 April 2021

DOI:

https://doi.org/10.32938/ja.v6i2.1359

Keywords:

Rumput Odot

Biochar

Teh Kompos

\section{Abstrak}

Tujuan dari penelitian ini untuk mengetahui pengaruh level biochar dan dosis teh kompos serta interaksinya terhadap pertumbuhan dan produksi rumput odot. Penelitian ini dilaksanakan pada 25 Mei 2020 sampai 3 Agustus 2020 bertempat di kebun percobaan Fakultas Pertanian Universitas Timor, Kelurahan sasi, Kecamatan Kota, Kabupaten Timor Tengah Utara. Metode yang digunakan dalam penelitian ini metode eksperimen menggunakan Rancangan Acak Lengkap (RAL) pola faktorial 3x3. Adapun Faktor yang diuji yaitu faktor pertama level biochar dan faktor kedua dosis teh kompos. Level biochar terdiri dari 3 taraf meliputi: $\mathrm{L}_{0}:$ Tanpa Biochar, $\mathrm{L}_{1}$ : Biochar $100 \mathrm{~g} /$ pot, $\mathrm{L}_{2}$ : Biochar $200 \mathrm{~g} /$ pot. Faktor kedua dosis teh kompos terdiri dari 3 taraf meliputi $\mathrm{D}_{0}$ : Tanpa Teh Kompos, $\mathrm{D}_{1}$ : Dosis $150 \mathrm{ml} /$ pot, $\mathrm{D}_{2}$ : Dosis $300 \mathrm{ml} /$ pot. Dari kedua faktor di atas dihasilkan 9 kombinasi perlakuan yang terdiri dari $\mathrm{L}_{0} \mathrm{D}_{0}, \mathrm{~L}_{0} \mathrm{D}_{1}, \mathrm{~L}_{0} \mathrm{D}_{2}, \mathrm{~L}_{1} \mathrm{D}_{0}$ $\mathrm{L}_{1} \mathrm{D}_{1}, \mathrm{~L}_{1} \mathrm{D}_{2}, \mathrm{~L}_{2} \mathrm{D}_{0}, \mathrm{~L}_{2} \mathrm{D}_{1}, \mathrm{~L}_{2} \mathrm{D}_{2}$ dan tiap kombinasi terdiri dari 4 ulangan sehingga terdapat 36 satuan percobaan. Variabel yang diamati yaitu Tinggi Tanaman (cm), Jumlah Anakan (Tunas), Diameter Batang, Berat Segar Daun (g), Berat Kering Daun (g). Hasil penelitian menunjukkan tidak terjadi interaksi antara level biochar dan dosis teh kompos terhadap tinggi tanaman, diameter batang, jumlah anakan, berat segar dan berat kering daun rumput odot. Disimpulkan bahwa produksi tanaman terbaik dihasilkan pada perlakuan kombinas biochar $200 \mathrm{~g} /$ pot dan dosis teh kompos $300 \mathrm{ml} /$ pot dan tidak terjadi interaksi antara level biochar dan dosis teh kompos terhadap pertumbuhan dan produksi rumput odot. Pemberian Biochar dengan level $200 \mathrm{~g}\left(\mathrm{~L}_{2}\right)$ secara nyata $(\mathrm{P}<0.05)$ mampu meningkatkan produksi berat segar sebesar $66.40 \mathrm{~g}$ dan berat kering tanaman $29.10 \mathrm{~g}$, namun tidak berpengaruh nyata $(\mathrm{P}>0.05)$ terhadap tinggi tanaman, diameter batang dan jumlah anakan yang dihasilkan. Pemberian dosis teh kompos $150 \mathrm{ml}\left(\mathrm{D}_{1}\right)$ memberikan hasil terbaik terhadap diameter batang yang dihasilkan sebesar $1.27 \mathrm{~cm}$ namun tidak berpengaruh terhadap variabel lain.

\section{Pendahuluan}

Produksi dan pertumbuhan merupakan aspek penting yang perlu diperhatikan dalam pemeliharaan hijauan. Budidaya hijauan sangat ditentukan oleh faktor lingkungan, kesuburan tanah, dan genetik. Pengembangan hijauan pakan diharapkan mampu menghasilkan produksi yang tinggi sehingga dapat menjamin ketersediaan pakan dalam waktu yang panjang. Budidaya hijauan merupakan salah satu kegiatan yang banyak dilakukan oleh masyarakat peternak. Salah satu hijauan yang sering dikembangkan adalah rumput odot.

Rumput odot atau rumput gajah mini (Pennisetum purpureum cv. Mott) adalah salah satu jenis rumput unggul yang dibutuhkan oleh ternak ruminansia dalam jumlah besar baik untuk hidup pokok, pertumbuhan, produksi, maupun reproduksi. Rumput odot memiliki keunggulan diantaranya tahan kekeringan, hanya bisa dipropagasi melalui metode vegetatif, zat gizi yang cukup tinggi dan memiliki palatabilitas yang tinggi bagi ternak ruminansia. Rumput odo memiliki kandungan karbohidrat struktural lebih rendah sehingga memiliki kecernaan yang tinggi serta dapat tumbuh pada berbagai macam tanah dan sangat responsif terhadap pemupukan (Lasamadi et al., 2013). Menurut Widodo (2015) keunggulan lain dari rumput odot yaitu batang relatif pendek dan empuk, pertumbuhannya relatif cepat, daun lembut dan tidak berbulu, mampu beradaptasi dengan kondisi lahan, tidak memerlukan perawatan khusus, dalam satu rumpun terdapat 50 - 80 batang dan sangat disukai ternak ruminansia dibandingkan rumput lainnya.

Pertumbuhan dan produksi tanaman sangat dipengaruhi oleh faktor kesuburan tanah, dimana kesuburan tanah dapat ditingkatkan melalui kegiatan pemupukan. Pemupukan didefinisikan sebagai penambahan suatu bahan kedalam tanah sehingga dapat menambah hara, merubah keaadaan fisik dan biologi tanah. Winarni et al. (2003) menyatakan bahwa tanaman yang kekurangan unsur nitrogen akan mengalami pertumbuhan yang lambat, kerdil, dan hijauan menjadi kekuningan, daunnya sempit dan tua serta cepa menguning dan mati. Pemberian pupuk kedalam tanah selain diberikan dalam bentuk padat seperti biochar juga dalam bentuk cair seperti teh kompos.

Biochar merupakan bahan pembenah tanah yang telah lama dikenal dalam bidang pertanian yang berupa bahan padat kaya karbon hasil konversi dari limbah organik (biomassa pertanian) melalui pembakaran tidak sempurna atau suplai oksigen terbatas (pyrolisis). Didalam tanah biochar menyediakan habitat yang baik bagi mikroba tanah misalnya bakteri yang membantu dalam perombakan unsur hara agar unsur hara tersebut dapat diserap oleh tanaman tetapi tidak dikonsumsi seperti bahan organik lainnya. Dalam jangka panjang biochar tidak mengganggu keseimbangan karbon-nitrogen, bahkan mampu menahan dan menjadikan air dan nutrient lebih tersedia bagi tanaman. Biochar dapat ditambahkan kedalam tanah dengan maksud untuk meningkatkan fungsi tanah dan untuk mengurangi emisi dari biomasa yang lain akan secara alami menurunkan gas rumah kaca. Bila digunakan sebagai pembenah tanah bersama pupuk organik dan anorganik biochar dapat meningkatkan produktivitas serta retensi dan ketersediaan hara bagi tanaman (Gani, 2009). Potensi biochar sebagai pembenah tanah selain dapat memperbaiki sifat fisik, kimia, dan biologi tanah dapat pula sebagai sumber utama bahan untuk konservasi karbon organik di dalam tanah. Pembenah biochar ke tanah meningkatkan ketersediaan kation utama dan fosfor, total $\mathrm{N}$ dan kapasitas tukar kation tanah (KTK) yang pada akhirnya dapat meningkatkan hasil. Setelah melalui proses produksi yang memenuhi persyaratan, biochar mengandung sekitar 50\% karbon yang ada dalam bahan dasar, sedangkan bahan organik yang terdekomposisi secara biologis biasanya mengandung karbon kurang dari 20\% setelah 5 - 10 tahun dan bahan organik apabila dibakar hanya meninggalkan $3 \%$ karbon. Manfaat biochar terletak pada dua sifat utamanya yaitu mempunyai daya serap hara yang tinggi dan persisten dalam tanah serta sebagai bahan amelioran tanah.

Ekskreta ayam merupakan salah satu bahan organik yang berpengaruh terhadap sifat fisik, kimia dan pertumbuhan tanaman. Ekskreta ayam mempunyai kadar unsur hara dan bahan organik yang tinggi serta kadar air yang rendah. Hasil analisis yang dilakukan oleh Suryani et al. (2010), bakteri yang ditemukan pada ekskreta ayam antara lain Lactobacillus achidophilus Lactobacillus reuteri, Leuconostoc mensenteroide dan Streptococcus thermophilus, sebagian kecil terdapat actinomycetes dan Kapang. Menurut Pangaribuan et al. (2012), pupuk ekskreta ayam memiliki kandungan unsur hara $\mathrm{N}, \mathrm{P}$ dan $\mathrm{K}$ yang lebih banyak dari pada pupuk kandang jenis ternak lainnya karena kotoran padat pada ternak unggas tercampur dengan kotoran cairnya. Penambahan kotoran ayam berpengaruh positif pada tanah masam berkadar bahan organik rendah karena pupuk organik mampu meningkatkan kadar P, K, Ca dan Mg tersedia. Menurut Subroto, (2009), pemberian pupuk dari ekskreta ayam dapat memperbaiki struktur tanah yang sangat kekurangan unsur organik serta dapat memperkuat akar tanaman. Raihan, (2000) menyatakan bahwa penggunaan bahan organik kotoran ayam mempunyai beberapa keuntungan antara lain sebagai pemasok hara tanah dan meningkatkan retensi air

Sufmuti (Chromolaena odorata L.), merupakan spesies berbunga semak dalam keluarga bunga matahari. Sufmuti mengandung unsur hara yang dapa dimanfaatkan sebagai pupuk organik. Di Indonesia tumbuhan sufmuti atau yang lebih dikenal dengan gulma siam ini memiliki dua sisi yang berbeda. Di satu sisi tumbuhan ini adalah gulma yang sangat merugikan karena tumbuhan ini bisa menjadi pesaing dalam penyerapan air dan unsur hara di dalam tanah, sehingga bisa berdampak pada pencapaian hasil pertanian, perkebunan, namun disisi lainnya tumbuhan ini bermanfaat bagi kelangsungan hidup manusia sebagai biopestisida, pupuk organik, serta obat, uniknya gulma ini dapat digunakan sebagai herbisida pembasmi gulma (Sugiyanto, 2013).

Sayre (2004) dan Syekhfani, (2006) menyatakan bahwa teh kompos dapat digunakan sebagai pupuk cair untuk pertumbuhan tanaman, meningkatkan kesehatan tanaman yang sekaligus membantu memproteks tanaman dari serangan penyebab penyakit (pathogen). Teh kompos memiliki beberapa keunggulan dan merupakan produk pupuk alami yang ramah lingkungan dan mampu menekan pertumbuhan bakteri patogen yang terdapa dalam teh kompos. Teh kompos juga dapat berfungsi sebagai pestisida alami karena teh kompos mampu mengembalikan kesuburan tanah secara alami serta meningkatkan daya tahan tanaman terhadap hama penyakit. Perbedaan teh kompos dan ekstrak kompos adalah pada ekstrak kompos menitikberatkan pada peningkatan kandungan nutrien tanah, sedangkan pada aplikasi teh kompos selain dapat meningkatkan kandungan nutrien tanah juga dapat meningkatkan populasi mikroorganisme yang bermanfaat untuk meningkatkan kesuburan tanah. Teh kompos yakni teh hasil ekstrak air kompos yang matang (Ingham, 2005). Kompos mengandung unsur-unsur hara yang dibutuhkan oleh tanaman dan mikroba yang bermanfaat bagi tanaman dan ekosistem tanah sehingg aplikasinya ke dalam tanah dapat memperbaiki kesuburan tanah dan meningkatkan ketahanan tanaman terhadap patogen melalui aktivitas mikroba yang terkandung di dalamnya.

Penggunaan teh kompos dan biochar sebagai pupuk diduga dapat memberikan manfaat antara lain menyediakan unsur hara bagi tanaman, menggemburkan tanah, memperbaiki struktur dan tekstur tanah, meningkatkan 
daya ikat tanah terhadap air, memudahkan pertumbuhan akar tanaman, menyimpan air tanah lebih lama, mencegah lapisan kering pada tanah, mencegah beberapa penyakit akar, harganya relatif murah, berkualitas dan ramah lingkungan, pemakaian lebih hemat, bersifat multi lahan karena bisa digunakan di lahan pertanian, perkebunan, dan reklamasi lahan kritis (Irwan et al., 2005).

\section{Metode Penelitian}

\subsection{Waktu dan Lokasi Penelitian}

Penelitian diilaksanakan di kebun percobaan Fakultas pertanian, Universitas Timor, Kelurahan Sasi, Kecamatan Kota Kefamenanu, Kabupaten Timor Tengah Utara, selama satu periode produksi (60 HST).

\subsection{Materi Penelitian}

\subsubsection{Alat dan Bahan}

Peralatan yang digunakan terdiri dari : alat ukur seperti penggaris, jangka sorong, timbangan digital, timbangan analitik, oven listrik, alat tulis, handspray dan peralatan pendukung yaitu alat bercocok tanam seperti : parang, ember dan gayung, linggis, pengayak tanah. Bahan yang digunakan seperti : Polibag kapasitas $5 \mathrm{~kg}$, stek rumput odot 2 pols ukuran $15 \mathrm{~cm}$ setiap polibag, sufmuti untuk pembuatan biochar, lamtoro dan ekstreta ayam untuk pembuatan kompos, dan $\mathrm{EM}_{4} 160 \mathrm{ml}$ dan tanah coklat (entisol).

\subsubsection{Rancangan Penelitian}

Penelitian ini merupakan penelitian eksperimen dengan menggunakan Rancangan Acak Lengkap (RAL) pola faktorial 3 x 3 . Adapun faktor yang diuji terdiri dari:

Faktor I. Level Biochar

$\mathrm{L}_{0} \quad=$ Tanpa Biochar

$\mathrm{L}_{1} \quad=$ Biochar $100 \mathrm{~g}$

$\mathrm{L}_{2} \quad=$ Biochar $200 \mathrm{~g}$

Faktor II. Dosis Teh Kompos (Takaran)

$\mathrm{D}_{0} \quad=$ Tanpa Teh Kompos

$\mathrm{D}_{1} \quad=$ Dosis $150 \mathrm{ml}$

$\mathrm{D}_{2} \quad=$ Dosis $300 \mathrm{ml}$

Dari kedua faktor di atas dihasilkan 9 kombinasi perlakuan yang terdiri dari: $\mathrm{L}_{0} \mathrm{D}_{0}, \mathrm{~L}_{0} \mathrm{D}_{1}, \mathrm{~L}_{0} \mathrm{D}_{2}, \mathrm{~L}_{1} \mathrm{D}_{0}, \mathrm{~L}_{1} \mathrm{D}_{1}, \mathrm{~L}_{1} \mathrm{D}_{2}, \mathrm{~L}_{2} \mathrm{D}_{0}, \mathrm{~L}_{2} \mathrm{D}_{1}, \mathrm{~L}_{2} \mathrm{D}_{2}$, masing-masing kombinasi terdiri dari 4 ulangan sehingga berjumlah 36 satuan percobaan.

\subsection{Prosedur Penelitian}

\subsubsection{Pembuatan Biochar}

Bahan baku biochar berupa sufmuti yang dikumpulkan setelah itu dipotong dengan ukuran $\pm 10 \mathrm{~cm}$ selanjutnya dikeringkan dengan cahaya matahari selama 24 jam. Sufmuti yang telah kering selanjutnya dibakar dengan menggunakan kontiki selama \pm 4 jam.

Proses pembuatan Biochar

1. Menempatkan paralon ditengah - tengah kontiki pada lubang sarangan.

2. Sufmuti dimasukkan kedalam kontiki setengah bagian sambil dipadatkan dan meletakan arang ke dalam paralon

3. Mengisi lagi kontiki dengan sufmuti sampai penuh.

4. Kontiki yang telah terisi penuh ditutup rapat.

5. Sufmuti dibakar dari bawah pembakaran sehingga lebih mudah perlakuannya.

6. Sufmuti yang terbakar sedikit demi sedikit akan jatuh kebawah sambil dibolak-balik menjadi arang sufmuti.

7. Arang sufmuti yang telah berwarna hitam dikeluarkan.

8. Arang sufmuti tersebut disiram dengan air bersih supaya arang tersebut tidak menjadi abu.

9. Arang sufmuti tersebut ditumbuk sampai halus dan disaring, kemudian dimasukkan kedalam karung dan siap untuk digunakan.

\subsubsection{Metode Pembuatan Teh Kompos}

Bahan pembuatan teh kompos berbahan dasar lamtoro (Leucaena leucocephala) dan ekskreta ayam.

Cara Pembuatannya

1. Mempersiapkan bahan yang akan digunakan untuk pembuatan pupuk kompos seperti ekskreta ayam, lamtoro (cacah), $\mathrm{EM}_{4}$, dan seng atau bahan lain untuk penutup.

2. Kemudian dibuat perbandingan antar ekskreta ayam dengan lamtoro $8: 2$.

3. Ekskreta ayam dan daun lamtoro dicampur secara manual hingga merata.

4. Larutkan $\mathrm{EM}_{4} 160 \mathrm{ml}$ ke dalam 7 liter air, kemudian memercikan larutan tersebut ke campuran bahan-bahan yang sudah dicampur sebelumnya secara perlahan pada bagian permukaannya.

5. Selanjutnya bahan - bahan yang telah dicampur ditutup dengan menggunakan karung dan seng dengan rapat sehingga menciptakan suasana anaerob.

6. Proses pengomposan membutuhkan waktu sekitar 21 hari yang ditandai dengan suhu panas dipermukaan bakal kompos. Selama proses ini, dilakukan pengadukan setiap 3 hari sekali untuk membantu proses aerasi

7. Pupuk kompos tersebut dimasukkan ke dalam karung dan siap untuk diaplikasikan.

\subsubsection{Pembuatan Teh Kompos}

Pembuatan teh kompos dengan melarutkan $1 \mathrm{~kg}$ kompos ke dalam 10 liter air $(1: 10)$. Pembuatan teh kompos dilakukan dengan mengaduk kompos yang telah dibungkus kain kasa ke dalam 10 liter air dengan menggunakan aerator selama 24 jam. Selanjutnya teh kompos yang telah dibuat dimasukkan dalam handspray dan siap diaplikasikan pada tanaman.

\subsubsection{Persiapan Media Tanam}

Media tanam yang digunakan berupa tanah jenis entisol yang telah disaring dimana tiap pot ditempatkan sebanyak $5 \mathrm{~kg}$ tanah dan dicampur dengan biochar sesuai perlakuan. Media tanam yang telah dibuat selanjutnya disiram dengan air sebanyak 2 liter dan diinkubasi selama 1 minggu sebelum ditanam.

\subsubsection{Inkubasi Media}

Sebelum dilakukan penanaman terlebih dahulu media tanam diinkubasi selama 1 minggu. Tiap pot diisi dengan biochar sesuai perlakuan. Tujuan inkubasi adalah untuk sebelum memberikan kesempatan agar mikroorganisme dapat hidup pada media tanam.

\subsubsection{Penanaman}

Penanaman rumput odot dilakukan setelah masa inkubasi. Setiap pot ditanami dengan 2 pols rumput odot yang telah dipotong dengan ukuran $15 \mathrm{~cm}$ dari pangkal batang. Setelah ditanam selanjutnya disiram menggunakan air sebanyak 2 liter pada setiap pot lalu dibiarkan selama kurang lebih satu minggu sebelum diberi perlakuan teh kompos.

\subsubsection{Pemberian Teh Kompos}

Pemberian perlakuan berupa penyemprotan teh kompos pada setiap tanaman dilakukan sesuai dosis yang disusun dan hasil pengacakan pada tiap pot. Pemberian teh kompos pada waktu 7 HST (hari setelah tanam) dimana tiap penyiraman diberikan sesuai dosis yang sudah ditentukan pada setiap pot.

\subsubsection{Pemeliharaan}

Pemeliharaan meliputi penyiraman dan pembersihan pada gulma. Penyiraman air dilakukan pada tiap hari bilamana tidak terjadi hujan, sedangkan pembersihan terhadap gulma dilakukan dengan mencabut jenis tanaman lain yang hidup pada pot.

\subsubsection{Pengambilan Data}

Pengambilan data tinggi tanaman, diameter batang, jumlah anakan diambil tiap minggu sekali, sedangkan data berat segar dan dan berat kering tanaman diambil pada masa akhir penelitian.

\subsection{Variabel Penelitian}

\subsubsection{Tinggi Tanaman (TTn)}

Tinggi tanaman diukur 14 hari setelah tanam dan diulang setiap 7 hari sampai tanaman mencapai pertumbuhan vegetatif maksimum. Pengukuran tinggi tanaman dilakukan dari permukaan tanah sampai bagian ujung batang, menggunakan mistar $(\mathrm{cm})$.

$$
\mathrm{TT}=\frac{\mathrm{TT} 1+\mathrm{TT} 2+\mathrm{TT} 3+\mathrm{TT} 4+\mathrm{TT} 5+\mathrm{TT} 6+\mathrm{TT} 7+\mathrm{TT} 8+\mathrm{TT} 9}{\mathrm{~T}}
$$

Keterangan:

\section{TT = Tinggi Tanaman}

TT1 = Tinggi tanaman pengukuran pertama

TT2 = Tinggi tanaman pengukuran kedua

TT3 = Tinggi tanaman pengukuran ketiga

TT4 = Tinggi tanaman pengukuran keempat

TT5 = Tinggi tanaman pengukuran kelima

TT6 = Tinggi tanaman pengukuran keenam

TT7 = Tinggi tanaman pengukuran ketujuh

TT8 = Tinggi tanaman pengukuran kedelapan

TT9 = Tinggi Tanaman pengukuran kesembilan

$\mathrm{T}=$ Waktu (minggu)

\subsubsection{Jumlah Anakan}

Jumlah anakan dihitung secara manual dengan cara menghitung setiap anakan yang tumbuh setiap minggu kemudian dilakukan perhitungan rataan jumlah anakan.

\subsubsection{Diameter Batang (DBt)}

Diameter batang diukur pada saat 14 hari setelah tanam diulang setiap 7 hari sampai tanaman mencapai pertumbuhan vegetatif maksimum. Alat yang digunakan untuk mengukur diameter batang adalah jangka sorong.

$$
\mathrm{DB}=\frac{\mathrm{DB} 1+\mathrm{DB} 2+\mathrm{DB} 3+\mathrm{DB} 4+\mathrm{DB} 5+\mathrm{DB} 6+\mathrm{DB} 7+\mathrm{DB} 8+\mathrm{DB} 9}{\mathrm{~T}}
$$

\section{Keterangan:}

DB = Diameter Batang

DB1 = Diameter Batang pengukuran pertama

$\mathrm{DB}_{2}=$ Diameter Batang Pengukuran Kedua

$\mathrm{DB}_{3}=$ Diameter Batang Pengukuran Ketiga 
$\mathrm{DB}_{4} \quad=$ Diameter Batang pengukuran keempat

$\mathrm{DB}_{5} \quad=$ Diameter Batang pengukuran kelima

$\mathrm{DB}_{6}=$ Diameter Batang pengukuran keenam

$\mathrm{DB}_{7} \quad=$ Diameter Batang Pengukuran Ketujuh

$\mathrm{DB}_{8} \quad=$ Diameter Batang Pengukuran Kedelapan

$\mathrm{DB}_{9} \quad=$ Diameter Batang pengukuran kesembilan

$\mathrm{T}=$ Waktu (minggu)

\subsubsection{Berat Segar Daun (BSD)}

Setelah tanaman berumur 60 hari setelah tanam, daun rumput odot dipanen, kemudian ditimbang. Data hasil penimbangan merupakan data berat segar daun (Santoso dan Hariyadi, 2008)

\subsubsection{Berat Kering Daun (BKD)}

Daun rumput odot yang sudah dikeringkan menggunakan matahari selama satu hari selanjutnya dikeringkan menggunakan oven pada suhu $70^{\circ} \mathrm{C}$ selama dua hari kemudian ditimbang. Data hasil penimbangan dicatat sebagai data berat kering daun (Santoso dan Hariyadi, 2008).

\subsection{Analisis Data}

Semua data yang dikumpulkan dianalisis dengan menggunakan analisis sidik ragam (ANOVA) sesuai dengan rancangan yang digunakan yaitu Rancangan Acak Lengkap (RAL) pola faktorial. Analisis data menggunakan Software SAS versi 9.0.

\section{Hasil dan Pembahasan}

\subsection{Tinggi Tanaman}

Tinggi tanaman merupakan salah satu gambaran kecepatan tumbuh tanaman yang dapat diukur persatuan waktu. Tinggi tanaman ditentukan salah satunya oleh ketersediaan hara pada tanah sehingga dapat digunakan sebagai sumber nutrien bagi tanaman. Tinggi tanaman yang dihasilkan pada penelitian ini dapat dilihat pada Tabel 1 .

Tabel 1. Pengaruh Perlakuan Terhadap Tinggi Tanaman Rumput Odot (cm).

\begin{tabular}{ccrrrr}
\hline \multirow{2}{*}{$\begin{array}{c}\text { Level Biochar } \\
(\mathrm{L})\end{array}$} & \multirow{6}{*}{ Ulangan } & \multicolumn{2}{c}{ Dosis Teh Kompos (D) } & Total Rataan \\
& & Kontrol & $150 \mathrm{ml}$ & $300 \mathrm{ml}$ & \\
\hline \multirow{4}{*}{ Kontrol } & 1 & 24,67 & 24,84 & 25,61 & \\
& 2 & 29,08 & 28,75 & 32,14 & 30,03 \\
& 3 & 61,82 & 29,84 & 27,50 & \\
\hline Rata-rata & 4 & 24,34 & 26,31 & 25,44 & $(-)$ \\
\hline & & 34,98 & 27,43 & 27,67 & \\
L-(100 g) & 2 & 28,50 & 34,94 & 30,16 & \\
& 3 & 27,29 & 29,64 & 28,94 & 29,26 \\
\hline Rata-rata & 4 & 27,60 & 23,96 & 23,34 & \\
\hline & & 29,42 & 29,71 & 28,63 & $(-)$ \\
L-(200 g) & 1 & 31,71 & 29,13 & 32,49 & \\
& 3 & 35,57 & 30,19 & 33,89 & 32,10 \\
\hline Rata-rata & 3 & 30,73 & 34,03 & 35,16 & \\
\hline Total Rataan & & 31,09 & 36,10 & 29,87 & $(-)$ \\
\hline
\end{tabular}

Keterangan : Angka yang diikuti superskrip yang sama menunjukkan berbeda tidaknyata $(P>0,05)$; (-) tidak terjadi interaksi antara faktor.

Hasil analisis sidik ragam menunjukkan tidak terjadi interaksi antara faktor level biochar dan dosis teh kompos $(\mathrm{P}>0,05)$ terhadap tinggi tanaman rumput odot yang dihasilkan. Analisis sidik ragam terhadap faktor level biochar dan dosis teh kompos tidak berpengaruh nyata $(\mathrm{P}>0.05)$ terhadap tinggi tanaman yang dihasilkan atau dengan kata lain bahwa antara perlakuan level biochar maupun dosis teh kompos memberikan pengaruh yang sama terhadap tinggi tanaman rumput odot yang dihasilkan. Hal ini karena rumput odot pada masa pertumbuhan awal lebih cenderung menambah akar dibandingkan meningkatkan tinggi tanaman. Menurut Sirait, (2017) bahwa dari segi pola pertumbuhannya, rumput odot memiliki karakter unik dimana pertumbuhan daunnya lebih mengarah ke samping dan rumput odot tumbuh membentuk rumpun dengan perakaran serabut yang kompak dan terus menghasilkan anakan apabila dipanen secara teratur.

Tanaman memilki unsur phosphor $(\mathrm{P})$ yang berfungsi untuk merangsang pertumbuhan akar, khususnya akar tanaman muda dan juga unsur kalium $(\mathrm{K})$ yang berfungsi untuk membentuk protein dan karbohidrat untuk tanaman. Menurut Purbajanti, (2013) fase pertumbuhan vegetatif tanaman terutama terjadi pada perkembangan akar, daun dan batang baru, dimana fase ini berhubungan dengan proses penting yaitu terjadinya pembelahan sel, perpanjangan sel dan tahap pertama dari diferensiasi sel. Lajunya pertumbuhan dan perkembangan suatu tanaman sangat tergantung dari aktivitas lajunya fotosintesis pada tanaman. Proses fotosintesis pada tanaman terjadi pada bagian daun dengan bantuan sinar matahari. Pemberian teh kompos dapat memperbaiki sifat fisik, kimia, dan biologi tanah, karena didalam teh kompos mengandung mikroorganisme yang berperan sebagai dekomposer. Kompos mengandung unsur-unsur hara yang dibutuhkan oleh tanaman dan mikrobia (bakteri, jamur, aktinomicetes) yang bermanfaat bagi tanaman dan ekosistem tanah sehingga aplikasinya ke dalam tanah dapat memperbaiki kesuburan tanah dan meningkatkan ketahanan tanaman terhadap patogen melalui aktivitas mikroba yang terkandung didalamnya. Sebagian mikroba yang terkandung di dalam kompos memiliki kapasitas kompetisi hara yang tinggi, memproduksi senyawa antibiosis, dan bersifat predator atau parasit, sehingga aplikasi kompos dapat meningkatkan ketahanan tanaman terhadap gangguan penyebab penyakit (Martin, 2015). Fakta tersebut menghadirkan ide teh kompos sebagai ekstrak unsur hara dan mikroba, serta senyawa lain dari kompos diberikan pada tanaman dengan dua tujuan yang dapat dicapai sekaligus, yakni menyediakan unsur hara terlarut yang lebih cepat tersedia untuk diserap tanaman dan pada saat yang bersamaan memberikan biopestisida (mikroba) pada tanaman untuk mencegah atau menekan serangan patogen. Sedangkan pemberian biochar mampu meningkatkan kualitas tanah karena didalam biochar mengandung senyawa organik dan anorganik.

\subsection{Diameter Batang}

Batang merupakan bagian tubuh tumbuhan yang amat penting bagi tumbuhan yang berada diatas permukaan tanah. Mengingat tempat dan kedudukannya bagi tubuh tumbuhan, batang dapat disamakan dengan sumbu tubuh tumbuhan. Hasil pengamatan diameter batang tanaman rumput odot terlihat pada Tabel 2 .

Tabel 2.Pengaruh Perlakuan Terhadap Diameter Batang Rumput Odot (cm).

\begin{tabular}{|c|c|c|c|c|c|}
\hline \multirow{2}{*}{$\begin{array}{l}\text { Level Biochar } \\
\text { (L) }\end{array}$} & \multirow{2}{*}{ Ulangan } & \multicolumn{3}{|c|}{ Dosis Teh Kompos (D) } & \multirow[t]{2}{*}{ Total Rataan } \\
\hline & & Kontrol & $150 \mathrm{ml}$ & $300 \mathrm{ml}$ & \\
\hline \multirow{4}{*}{ Kontrol } & 1 & 1,20 & 1,31 & 1,06 & \multirow{4}{*}{1,24} \\
\hline & 2 & 1,22 & 1,33 & 1,31 & \\
\hline & 3 & 1,39 & 1,37 & 1,10 & \\
\hline & 4 & 1,21 & 1,23 & 1,16 & \\
\hline Rata-rata & & 1,25 & 1,31 & 1,16 & $(-)$ \\
\hline \multirow{4}{*}{ L-(100 g) } & 1 & 1,19 & 1,51 & 1,21 & \multirow{4}{*}{1,20} \\
\hline & 2 & 1,21 & 1,33 & 1,19 & \\
\hline & 3 & 1,24 & 1,21 & 1,14 & \\
\hline & 4 & 0,87 & 1,11 & 1,13 & \\
\hline Rata-rata & & 1,13 & 1,29 & 1,17 & $(-)$ \\
\hline \multirow{4}{*}{$\mathrm{L}-(200 \mathrm{~g})$} & 1 & 1,12 & 1,22 & 1,18 & \multirow{4}{*}{1,19} \\
\hline & 2 & 1,00 & 1,13 & 1,32 & \\
\hline & 3 & 1,22 & 1,29 & 1,22 & \\
\hline & 4 & 1,07 & 1,24 & 1,22 & \\
\hline Rata-rata & & 1,10 & 1,22 & 1,24 & $(-)$ \\
\hline Total Rataan & & $1,16^{\mathrm{b}}$ & $1,27^{\mathrm{a}}$ & $1,19^{\mathrm{ab}}$ & \\
\hline
\end{tabular}

Hasil analisis sidik ragam menunjukkan tidak terjadi interaksi antara faktor level biochar dan dosis teh kompos terhadap perubahan diameter batang rumput odot. Perubahan diameter batang rumput odot lebih dipengaruhi oleh faktor dosis teh kompos $(\mathrm{P}<0.05)$ sedangkan faktor level biochar tidak berpengaruh nyata $(\mathrm{P}>0.05)$.

Dosis teh kompos terbaik ditunjukan pada perlakuan $\mathrm{D}_{1}(150 \mathrm{ml})$ yang menghasilkan diameter batang sebesar $1.27 \mathrm{~cm}$ diikuti $\mathrm{D}_{2}(300 \mathrm{ml})$ dan yang terendah pada perlakuan $\mathrm{D}_{0}$ (Kontrol) $1.16 \mathrm{~cm}$. Tingginya diameter batang yang dihasilkan pada perlakuan $\mathrm{D}_{1}(150 \mathrm{ml})$ disebabkan karena pada dosis tersebut kondisi lingkungan tanah mampu menyediakan mikroba yang dibutuhkan dalam penguraian bahan organik sehingga mampu menghasilkan diameter batang yang lebih baik dari perlakuan lainnya. Bakteri yang membantu dalam perombakan unsur hara agar unsur hara tersebut dapat diserap oleh tanaman dan menstimulasi simbiosis fiksasi Nitrogen, bahkan mampu menahan dan menjadikan air dan nutrisi lebih tersedia bagi tanaman.

Diameter tanaman rumput odot mengalami peningkatan karena adanya penambahan jumlah sel sebagai hasil pembelahan mitosis. Meningkatnya jumlah organisme tanah terutama organisme penambat $\mathrm{N}$ mampu menunjang pertumbuhan dan hasil tanaman (Gani, 2010). Pemberian teh kompos ekskreta ayam meningkatkan ketersediaan $\mathrm{N}$ tanah sehingga mampu mencukupi kebutuhan tanaman. Menurut Pangaribuan et al. (2012), pupuk ekskreta ayam memiliki kandungan unsur hara N, P dan K yang lebih banyak dari pada pupuk kandang jenis ternak lainnya karena kotoran padat pada ternak unggas tercampur dengan kotoran cairnya nitrogen diketahui merupakan salah satu unsur yang berperan penting dalam proses pembelahan dan pembesaran sel 
yang merupakan dasar dari pertumbuhan tanaman, seperti pertambahan tinggi tanaman. Ekskreta ayam terdiri dari sisa pakan dan serat selulosa yang tidak dicerna. Ekskreta ayam mengandung protein, karbohidrat, lemak, dan senyawa organik lainnya. Protein pada ekskreta ayam merupakan sumber nitrogen adapula bentuk nitrogen inorganik lainnya. Komposisi ekskreta ayam sangat bervariasi tergantung pada jenis ayam, umur, keadaan individu ayam, dan makanan (Foot et al., 1976). Ekskreta ayam memiliki kandungan unsur hara P0 $80 \%$, K0 40\%, kadar air 55\% dan N1\% (Lingga, 1986). Dalam teh kompos ekskreta ayam juga terdapat mikroorganisme antagonis yang membunuh pathogen sehingga kesehatan tanaman lebih terjaga. Dengan demikian penggunaan teh kompos menghasilkan sistem drainase yang baik, memiliki daya intermolekul yang dapat mempengaruhi kecepatan perkecambahan, dan pembelahan sel. Kandungan unsur-unsur hara itu ada yang dapat mempercepat pertumbuhan tanaman (Glasser et al., 2002; Lehmann et al., 2003; Lehmann dan Rondon, 2006; Steiner et al., 2007). Sedangkan pemberian level biochar tidak memberikan pengaruh terhadap pertumbuhan rumput odot. Hal ini diduga pemberian level biochar lebih berpengaruh terhadap poduksi berat segar dan berat kering daun. Biochar yang diaplikasikan ke dalam tanah secara nyata berpotensi dalam meningkatkan beberapa sifat kimia tanah.

\subsection{Jumlah Anakan}

Jumlah anakan merupakan salah satu bagian yang menunjukkan pertumbuhan dan perkembangan tanaman pada fase vegetatif. Jumlah anakan pada tanaman berumpun akan terus meningkat apabila rumput tidak terserang hama dan penyakit

Tabel 3.Pengaruh perlakuan terhadap jumlah anakan (Rumpun)

\begin{tabular}{|c|c|c|c|c|c|}
\hline \multirow{2}{*}{$\begin{array}{c}\text { Level Biochar } \\
\text { (L) }\end{array}$} & \multirow{2}{*}{ Ulangan } & \multicolumn{3}{|c|}{ Dosis Teh Kompos (D) } & \multirow[t]{2}{*}{ Total Rataan } \\
\hline & & Kontrol & $150 \mathrm{ml}$ & $300 \mathrm{ml}$ & \\
\hline \multirow{4}{*}{ Kontrol } & 1 & 9,44 & 5,67 & 7,89 & \multirow{4}{*}{8,42} \\
\hline & 2 & 9,67 & 7,00 & 7,89 & \\
\hline & 3 & 7,89 & 7,33 & 9,78 & \\
\hline & 4 & 9,56 & 6,89 & 12,00 & \\
\hline Rata-rata & & 9,14 & 6,72 & 9,39 & $(-)$ \\
\hline \multirow{4}{*}{$\mathrm{L}-(100 \mathrm{~g})$} & 1 & 6,89 & 9,22 & 9,78 & \multirow{4}{*}{8,29} \\
\hline & 2 & 8,44 & 10,33 & 9,44 & \\
\hline & 3 & 8,44 & 9,11 & 6,78 & \\
\hline & 4 & 4,67 & 5,67 & 10,67 & \\
\hline Rata-rata & & 7,11 & 8,58 & 9,17 & $(-)$ \\
\hline \multirow{4}{*}{ L- $(200 \mathrm{~g})$} & 1 & 9,78 & 9,56 & 6,33 & \multirow{4}{*}{8,72} \\
\hline & 2 & 7,56 & 6,78 & 12,11 & \\
\hline & 3 & 6,44 & 9,89 & 11,56 & \\
\hline & 4 & 6,44 & 9,78 & 8,44 & \\
\hline Rata-rata & & 7,56 & 9,00 & 9,61 & $(-)$ \\
\hline Total Rataan & & 7,94 & 8,10 & 9,39 & \\
\hline
\end{tabular}

Keterangan : Angka yang diikuti superskrip yang sama menunjukkan tidak berbeda nyata $(P<0,05)$; (-) tidak terjadi interaksi antara faktor.

Hasil analisis sidik ragam (Anova) memperlihatkan bahwa tidak terjadi interaksi antara level biochar dan dosis teh kompos terhadap jumlah anakan rumput odot yang dihasilkan. Selain itu antara perlakuan level biochar dan dosis teh kompos memberikan pengaruh yang tidak berbeda nyata $(\mathrm{P}>0.05)$ atau dapat dikatakan bahwa pemberian biochar pada berbagai level dan teh kompos pada berbagai dosis dalam penelitian ini memberikan pengaruh yang sama terhadap jumlah anakan rumput odot yang dihasilkan.

Hasil penelitian Annicchiarico et al. (2011) melaporkan bahwa kandungan $\mathrm{N}$ dan $\mathrm{P}$ yang ada pada lahan subur akibat penggunaan pupuk organik akan memperbaiki jaringan meristem tanaman. Menurut Adele et al. (2011) bahwa pupuk organik merupakan pensuplai N, meningkatkan gerak dan ketersediaan unsur $\mathrm{P}$ dan unsur mikro, meningkatkan retensi kelembaban, memperbaiki struktur tanah dengan peningkatan kegemburan dan pengurangan berat jenis tanah. Pertambahan jumlah anakan berkaitan erat dengan unsur hara makro salah satunya adalah unsur Nitrogen. Unsur Nitrogen dibutuhkan tanaman untuk pembentukan klorofil dan protein. Menurut Rellam et al. (2017) unsur Nitrogen berfungsi sebagai penyusun dari banyak senyawa esensial bagi tumbuhan, misalnya asam-asam amino. Semakin banyak unsur hara Nitrogen yang diserap tanaman akan meningkatkan pertumbuhan dan perkembangan tanaman. Disisi lain teh kompos juga memberikan pengaruh yang nyata terhadap pertumbuhan rumput odot. Sayre, (2004) dan Syekhfani, (2006) menyatakan bahwa teh kompos dapat digunakan sebagai pupuk cair untuk pertumbuhan tanaman, meningkatkan kesehatan tanaman yang sekaligus membantu memproteksi tanaman dari serangan penyebab penyakit (patogen). Kompos mengandung unsur-unsur hara yang dibutuhkan oleh tanaman dan mikrobia (bakteri, jamur, aktinomicetes) bermanfaat bagi tanaman dan ekosistem tanah sehingga aplikasinya ke dalam tanah dapat memperbaiki kesuburan tanah dan meningkatkan ketahanan tanaman terhadap patogen melalui aktivitas mikroba yang terkandung didalamnya. Sebagian mikroba yang terkandung di dalam kompos memiliki kapasitas kompetisi hara yang tinggi, memproduksi senyawa antibiosis, dan bersifat predator atau parasit, sehingga aplikasi kompos dapat meningkatkan ketahanan tanaman terhadap gangguan penyebab penyakit (Martin, 2015).

\subsection{Berat Segar Daun}

Berat segar merupakan total berat tanaman yang menunjukkan hasil aktivitas metabolik suatu tanaman. Hasil pengamatan terhadap berat segar daun pada tanaman rumput odot seperti terlihat pada Tabel 4.

Tabel 4. Pengaruh Perlakuan Terhadap Berat Segar Daun (g)

\begin{tabular}{|c|c|c|c|c|c|}
\hline \multirow{2}{*}{$\begin{array}{l}\text { Level Biochar } \\
\text { (L) }\end{array}$} & \multirow{2}{*}{ Ulangan } & \multicolumn{3}{|c|}{ Dosis Teh Kompos (D) } & \multirow[t]{2}{*}{ Total Rataan } \\
\hline & & Kontrol & $150 \mathrm{ml}$ & $300 \mathrm{ml}$ & \\
\hline \multirow{4}{*}{ Kontrol } & 1 & 45,00 & 40,67 & 37,46 & \multirow{4}{*}{$49,92^{b}$} \\
\hline & 2 & 51,65 & 44,61 & 64,27 & \\
\hline & 3 & 48,00 & 55,07 & 69,43 & \\
\hline & 4 & 38,31 & 51,54 & 53,01 & \\
\hline Rata-rata & & 45,74 & 47,97 & 56,04 & $(-)$ \\
\hline \multirow{4}{*}{$\mathrm{L}-(100 \mathrm{~g})$} & 1 & 45,46 & 70,56 & 57,94 & \multirow{4}{*}{$51,41^{b}$} \\
\hline & 2 & 51,95 & 62,45 & 56,35 & \\
\hline & 3 & 50,00 & 51,34 & 50,90 & \\
\hline & 4 & 36,19 & 35,00 & 48,73 & \\
\hline Rata-rata & & 45,90 & 54,84 & 53,48 & $(-)$ \\
\hline \multirow{4}{*}{ L-(200 g) } & 1 & 63,75 & 61,60 & 47,57 & \multirow{4}{*}{$66,40^{\mathrm{a}}$} \\
\hline & 2 & 57,23 & 75,38 & 90,36 & \\
\hline & 3 & 62,69 & 67,00 & 78,89 & \\
\hline & 4 & 39,57 & 91,86 & 60,95 & \\
\hline Rata-rata & & 55,81 & 73,96 & 69,44 & $(-)$ \\
\hline
\end{tabular}

Total Rataan

$49,15 \quad 58,92 \quad 59,66$

Keterangan : Angka yang diikuti superskrip yang tidk sama menunjukkan berbeda; nyata $(P<0,05)$; (-) tidak terjadi interaksi antara faktor.

Hasil analisis sidik ragam (Anova) menunjukkan bahwa tidak terjadi interaksi antara faktor level biochar dan dosis teh kompos terhadap produksi berat segar tanaman yang dihasilkan. Peningkatan produksi berat segar tanaman lebih dipengaruhi oleh faktor Level Biochar $(\mathrm{P}<0.05)$ sedangkan dosis teh kompos tidah berbeda nyata $(\mathrm{P}>0.05)$.

Produksi berat segar tanaman terbaik pada faktor level biochar dihasilkan pada perlakuan $\mathrm{L}_{2}(200 \mathrm{~g})$ sebesar $66,40 \mathrm{~g}$ diikuti perlakuan $\mathrm{L}_{1}(100$ g) sebesar $51.41 \mathrm{~g}$ dan yang terendah pada perlakuan $\mathrm{L}_{0}$ (kontrol) sebesar 49.92 g. Tingginya produksi berat segar pada perlakuan $\mathrm{L}_{2}(200 \mathrm{~g})$ disebakan karena biochar mampu menyuplai karbon aktif dalam bentuk $\mathrm{Ca}$ (Kalsium) dan $\mathrm{Mg}$ (Magnesium) dan karbon anorganik sehingga dapat menjaga $\mathrm{pH}$ tanah dan meningkatkan sifat fisik dan biologi tanah serta kapasitas tukar kation (KTK) sehingga dapat diserap untuk pertumbuhan dan peningkatan hasil produksi tanaman. Menurut Dou et al. (2012) biochar berpengaruh langsung terhadap tanaman. Perbaikan sifat fisika menyebabkan jangkauan perakaran tanaman semakin luas sehingga memudahkan tanaman untuk mendapatkan nutrisi dan air yang dibutuhkan dalam pertumbuhannya. Selain itu, amandemen biochar juga dapat memperbaiki struktur, porositas, dan formasi agregat tanah (Lehmann dan Joseph, 2009). Menurut Rao dan Subha, (1994) perbaikan sifat fisik, kimia dan biologi tanah dengan penambahan bahan organik dapat memberikan dukungan bagi media yang berfungsi sebagai pensuplai air, oksigen dan hara bagi tanaman. Dilaporkan oleh Sutedjo dan Kartasapoetra, (2004) meningkatnya kandungan bahan organik pada tanah dapat menurunkan tingkat erodibilitas tanah karena bahan organik dapat mengikat dan mempertahankan kemantapan struktur tanah. Lebih lanjut Lingga dan Marsono, (2003) menyatakan bahwa tanah yang berstruktur baik, dengan kata lain tanah yang banyak mengandung mikroorganisme dan kepadatan tanah yang berkurang dapat menyerap air dan unsur hara yang terlarut.

\subsection{Berat Kering Daun}

Berat kering tanaman merupakan parameter pengamatan yang digunakan untuk mengetahui kandungan biomassa dan air yang terkandung pada tanaman. Berat kering tanaman dilakukan pengamatan dengan cara menimbang berat segar tanaman terlebih dahulu setelah diketahui berat segar tanaman kemudian dilakukan pengeringan hingga kadar air yang terkandung hilang kemudian dilakukan penimbangan. Pengeringan yang berlangsung pada umumnya dilakukan dengan temparatur berkisar $70^{\circ} \mathrm{c}$ hasil pengamatan terhadap berat kering daun tanaman rumput odot seperti terlihat pada Tabel 5. 
Tabel 5. Pengaruh Perlakuan Terhadap Berat Kering Daun (g)

\begin{tabular}{|c|c|c|c|c|c|}
\hline \multirow{2}{*}{$\begin{array}{l}\text { Level Biochar } \\
\text { (L) }\end{array}$} & \multirow{2}{*}{ Ulangan } & \multicolumn{3}{|c|}{ Dosis Teh Kompos (D) } & \multirow[t]{2}{*}{ Total Rataan } \\
\hline & & Kontrol & $150 \mathrm{ml}$ & $300 \mathrm{ml}$ & \\
\hline \multirow{4}{*}{ Kontrol } & 1 & 18.91 & 18.44 & 15.91 & \multirow{4}{*}{$20.18^{\mathrm{b}}$} \\
\hline & 2 & 23.99 & 20.42 & 26.44 & \\
\hline & 3 & 20.55 & 23.32 & 19.42 & \\
\hline & 4 & 13.38 & 24.72 & 16.69 & \\
\hline Rata-rata & & 19.21 & 21.73 & 19.62 & $(-)$ \\
\hline \multirow{4}{*}{ L-(100 g) } & 1 & 21.01 & 33.95 & 26.44 & \multirow{4}{*}{$22.14^{\mathrm{b}}$} \\
\hline & 2 & 23.63 & 28.33 & 20.77 & \\
\hline & 3 & 20.80 & 23.30 & 20.70 & \\
\hline & 4 & 14.58 & 13.80 & 18.33 & \\
\hline Rata-rata & & 20.01 & 24.85 & 21.56 & $(-)$ \\
\hline \multirow{4}{*}{ L-(200 g) } & 1 & 27.44 & 34.54 & 28.40 & \multirow{4}{*}{$29.11^{\mathrm{a}}$} \\
\hline & 2 & 25.61 & 19.32 & 39.42 & \\
\hline & 3 & 29.09 & 26.81 & 31.75 & \\
\hline & 4 & 18.40 & 44.09 & 24.39 & \\
\hline Rata-rata & & 25.14 & 31.19 & 30.99 & $(-)$ \\
\hline Total Rataan & & 21.45 & 25.92 & 24.06 & \\
\hline
\end{tabular}

Hasil analisis sidik ragam (Anova) menunjukkan bahwa tidak terjadi interaksi $(\mathrm{P}>0.05)$ antara faktor level biochar dan dosis teh kompos terhadap produksi bahan kering tanaman yang dihasilkan. Produksi bahan kering tanaman lebih dipengaruhi oleh faktor level biochar $(\mathrm{P}<0.05)$ sedangkan dosis teh kompos tidak berpengaruh nyata $(\mathrm{P}>0.05)$. Produksi bahan kering tertinggi pada faktor level biochar dihasilkan pada tanaman yang mendapat perlakuan $\mathrm{L}_{2}$ $(200 \mathrm{~g})$ sebesar $29.11 \mathrm{~g}$ diikuti perlakuan $\mathrm{L}_{1}(100 \mathrm{~g})$ sebesar $22.14 \mathrm{~g}$ dan yang terendah pada perlakuan $\mathrm{L}_{0}$ (kontrol) sebesar $20.18 \mathrm{~g}$. Tingginya produksi bahan kering yang dihasilkan pada perlakuan $\mathrm{L}_{2}(200 \mathrm{~g})$ sejalan dengan produksi bahan segar yang dihasilkan, sehingga dapat dikatakan bahwa produksi bahan kering tanaman akan ditentukan juga oleh produksi bahan segar yang dihasilkan.

Meningkatnya hasil perhitungan jumlah biomassa berupa berat kering daun pada penelitian ini diduga dipengaruhi oleh laju produksi biomassa yang berbeda pada setiap rumpun rumput odot, dimana menurut (Niinemets, 2007) laju produksi biomassa (bahan kering) tanaman tergantung laju akumulasi biomassa harian dikurangi kehilangan biomassa oleh proses fisiologi seperti respirasi. Selain itu, akumulasi biomassa suatu tanaman dipengaruhi oleh umur, dan ketersediaan hara tanah. Menurut Mansyur et al. (2004) proporsi berat kering tanaman yang dikandung oleh rumput berubah seiring dengan umur tanaman, makin tua tanaman maka akan lebih sedikit kandungan airnya dan proporsi dinding sel lebih tinggi dibandingkan dengan isi sel. Apabila kandungan dinding sel yang dimiliki tanaman lebih besar maka tanaman tersebut akan lebih banyak mengandung berat kering.

\section{Simpulan}

Kesimpulan dari penelitian ini ialah:

1. Tidak terjadi interaksi antara level biochar dan dosis teh kompos terhadap pertumbuhan dan produksi rumput odot.

2. Pemberian biochar dengan level $200 \mathrm{~g}\left(\mathrm{~L}_{2}\right)$ secara nyata $(\mathrm{P}<0.05)$ mampu meningkatkan produksi berat segar sebesar $66.40 \mathrm{~g}$ dan berat kering tanaman $29.10 \mathrm{~g}$, namun tidak berpengaruh nyata ( $>0.05)$ terhadap tinggi tanaman, diameter batang dan jumlah anakan yang dihasilkan.

3. Pemberian dosis teh kompos $150 \mathrm{ml}\left(\mathrm{D}_{1}\right)$ memberikan hasil terbaik terhadap diameter batang yang dihasilkan sebesar $1.27 \mathrm{~cm}$ namun tidak berpengaruh terhadap variable lain dalam penelitian ini.

\section{Daftar Pustaka}

Adele, K., L. Piere and J. C. Thouret. 2011. Environmental changes in the highlands of the western Andean Cordillera. Southern Peru. The Holocene 1-12.

Annicchiarico, G., G. Caternolo, E. Rossi, dan P. Martiniello. 2011. Pengaruh input pupuk vs. pupuk terhadap produktivitas model tanaman hijauan. int.j.environ.res.public health 8: 1893-1913. Int. J. Environ. Res. Public Health 8:1893-1913.
Dou, L., M. Komatsuzaki, dan M. Nakagawa. 2012. Efek Aplikasi Biochar, Mokusakueki dan Bokashi pada Nutrisi Tanah, Hasil dan Kualitas Ubi Jalar. J. Ilmu Pertanian dan Ilmu Tanah. 2: 318-327.

Foot, A.S., Banes, S., Ja. C.G O go, Howkins J. C., Nielsen, V.C, And Jr.O. Collaghan. 1976. Studies on Farm Livestock Waste I" ed. Agriculture Research Council, England

Gani, A. 2009. Potensi Arang Hayati Biochar Sebagai Komponen Teknologi Perbaikan Produktivitas Lahan Pertanian. Iptek Tanaman Pangan Vol. 4 No. 1. Balai Besar Penelitian Tanaman Padi. Sukamandi. Hal 33-48

Gani, A. 2010. Multiguna Arang-Hayati Biochar. Balai Besar Penelitian Tanaman Padi. Sinar Tani. Edisi 13-19: hal 1-4.

Glaser, B., J. Lehmann, dan W. Zech. 2002. Mengurangi sifat fisik dan kimia tanah yang sangat lapuk di daerah tropis dengan arang: Sebuah ulasan. Biol. Fertil. Tanah 35: 219-230.

Ingham, E. R. 2005. Manual menyeduh teh kompos. Soil Foodweb Inc. Oregon, AS.

Irwan, A. W., A. Wahyudin.,R. Susilawati dan T. Nurmala. 2005. Interaksi Jarak Tanam dan Jenis Pupuk Kandang Terhadap Komponen Hasil dan Kadar Tepung Sorghum (Sorghum tricolor Linn. Moench) pada Inseptisol di Jatinangor MH 2004. J. Kultivasi 4 (2) : 128 -136.

Lasamadi, R. D., S. S. Malalantang, Rustandi dan S. D. Anis. 2013 Pertumbuhan dan perkembangan rumput gajah mini (Pennisetum purpureum cv. Mott) yang diberi pupuk organik hasil fermentasi EM4. Jurnal Zootek. 32 (5): 158-171.

Lehman J dan Joseph, S. 2007. Biochar untuk Manajemen Lingkungan:Sebuah Inroduksi. Science and Technology (Johannes Lehman dan Stephen joseph Eds) Pertama kali diterbitkan oleh Earthscan di Inggris dan Amerika Serikat pada tahun 2009. 12 pp

Lehmann J., JP da Silva Jr, C. Steiner, T. Nehls, W. Zech dan B. Glaser. 2003. Ketersediaan Nutrisi dan Leaching dalam Antrosol Arkeologi dan Ferralsol dari Cekungan Amazon Tengah: Amandemen Pupuk, Pupuk Kandang dan Arang. Tanaman dan Tanah. 249: $343 \pm 357$

Lehmann, J. dan M. Rondon. 2006. Pengelolaan bio-char soil pada tanah yang sangat lapuk di daerah tropis lembab di N. Uphoff (Eds.). Pendekatan Biologis untuk Sistem Tanah Berkelanjutan. P 517-530. CRP Press. Amerika serikat.

Lingga, P. dan Marsono. 2003. Petunjuk penggunaan pupuk. Penerbit Swadaya. Jakarta.

Lingga, P. 1986. Petunjuk Penggunaan Pupuk. Penebar Swadaya . Jakarta.

Mansyur, S. Hardjosoewignyo dan L. Abdullah. 2004. Respon Rumput Brachiaria humudicola (Rendle) Schweick Terhadap Interval Pemotongan. Jurnal Ilmu Ternak, 4 (2): 57 - 61.

Kimetsu, U., 2007. Fotosintesis dan distribusi sumber daya melalui tajuk tanaman. Tanaman, Sel dan Lingkungan, 30, hlm. 1052-1071.

Pangaribuan D. H, Yasir M, Utami, N. K. 2012. Dampak Bokashi Kotoran Ternak dalam Pengurangan Pemakaian Pupuk Anorganik pada Budidaya Tanaman Tomat. J. Agron. Indonesia 40 (3): 204-210.

Purbajanti, E.D. 2013. Rumput dan Legum Sebagai Hijauan MakananTernak Graha Ilmu. Yogyakarta.

Raihan, H. S. 2000. Pemupukan NPK dan ameliorasi lahan pasang surut sulfat masam berdasarkan nilai uji tanah untuk tanaman jagung. J. Ilmu Pertanian 9 (1): 20-28.

Rao dan N.S. Subha. 1994. Mikroorganisme Tanah dan Pertumbuhan Tanaman. Penerbit Universitas Indonesia Jakarta.

Rellam CR, Anis S, Rumambi A, Rustandi. 2017. Pengaruh naungan dan pemupukan nitrogen terhadap karakteristik morfologis rumput gajah dwarf (Pennisetum purpureum cv. Mott). J Zootek. 37:179185.

Santoso, B. B. dan Hariyadi. 2008. Metode Pengukuran Luas Daun Jarak Pagar (Jatropha curcas L.). Magrobis Jurnal Ilmu-ilmu Pertanian 8 (1): 17-22.

Sayre, L. 2004. Penelitian Teh Kompos Memasuki Tahun Kedua. Penelitian Pertanian Baru.

St. Martin, C.C.G. 2015. Meningkatkan daya tekan tanah menggunakan kompos dan teh kompos. Di: M.K. Meghvansi, A. Varma (eds.), Amandemen Organik dan Penindasan Tanah dalam Manajemen Penyakit Tanaman, Biologi Tanah 46. Springer International Publishing. Swiss.

Steiner, C., W. G. Teixeira, J. Lehmann, T. Nehls, J. L.V. de Macêdo, W. E. H. Blum, W. Zech. 2007. Efek jangka panjang dari pupuk kandang, arang dan pemupukan mineral pada produksi tanaman dan kesuburan di dataran tinggi Amazon Tengah yang sangat lapuk. Tanah tanaman 291 275-290

Subroto. 2009. Kesuburan dan Pemupukan Tanah Pertanian. Pustaka Buana, Bandung

Sugiyanto, 2013. Kirinyuh (Chromolaena odorata), Gulma Dengan Banyak Potensi Manfaat. Kementerian Pertanian.Direktorat Jenderal Perkebunan (Online) (http://ditjenbun.pertanian.go.id/), diakses 02 Januari 2020

Suryani, Yoni, Astuti, Barnadeta, Oktavia, dan Siti Ummiyati. 2010. "Isolasi dan Karakteristik Bakteri Asam Laktat dari Limbah Kotoran Ayam sebagai Agensi Probiotik dan Enzim Kolesterol Reduktase”. Prosiding Seminar Nasional Biologi Yogyakarta. Hal: 138-147.

Sutedjo, M. M dan Kartasapoetra A. G.. 2004. Pengantar Ilmu Tanah Terbentuknya Tanah dan Tanah Pertanian. Rineka Cipta. Jakarta. 
Syekhfani. 2006. Teknologi Teh Kompos untuk Mendukung Sistem Pertanian Berkelanjutan. Pelatihan Dosen-Dosen Se-Jawa dan Bali. Kerjasama BKSDM Dikjen Dikti Depdiknas Universitas Brawijaya Malang.

Widodo, K. 2015. Rumput Gajah Mini (Pennisetum purpureum cv. Mott). [serial online]. www.facebook.com/paguyuban peternak sapi nusantara.[Diakses pada tanggal 4 Maret 2020.]

Winarni, E. Rita Dwi Ratnani dan Indah Riwayati. 2003. Pengaruh Jenis Pupuk Organik Terhadap Pertumbuhan Tanaman Kopi. Jurnal Momentum. 9(1) April 2003. Hal.35-39. 